\title{
Die Anglo-Boereoorlog (1899-1902) in die Afrikaanse letterkunde: 'n geheelperspektief
}

\author{
$A$ WESSELS $S^{1}$
}

\begin{abstract}
This study reviews Afrikaans literary works (poems, plays, novels and short stories) dealing with the Anglo-Boer War (1899-1902). War poems written by wellknown Afrikaans poets such as Jan F.E. Celliers, Eugène Marais, C. Louis Leipoldt, Totius and D.J. Opperman, as well as some of the few plays that have the war as background, receive attention. See in this regard, for example, N.P. van Wyk Louw's Die pluimsaad waai ver of bitter begin, which in its day elicited a substantial amount of controversy. In addition to the short stories that deal with the war, many novels on the war have also been published. Attention is drawn to the fact that the upsurge in Afrikaner nationalism in the 1930s (and later) went hand-in-hand with the publication of Anglo-Boer War novels. The youth was also not neglected, thanks to best-selling books on the war by Mikro and others. Etienne Leroux's controversial novel Magersfontein, o Magersfontein! (1976) paved the way for several other noteworthy war novels that demythologise the Afrikaner's so-called heroic role in the war. The article also identifies the most important topics that have thus far been explored in the Afrikaans literature on the war, for example the role played by Cape rebels; the consequences of the British scorched-earth policy and concomitant camps for white and black civilians; feminism, and the role and experiences of black and coloured people. In conclusion, the mutually enriching relationship between history and literature is investigated.
\end{abstract}

Keywords: Afrikaans literature, Anglo-Boer War (1899-1902), Cape rebels, black civilians, faminism, relations history and literarture.

Subjects: Military history, Literature Studies, South African Studies.

\section{Executive summary}

The Anglo-Boer War (1899-1902) and Afrikaans literature: a reappraisal

Many thousands of scholarly books and articles have been written on the history of the Anglo-Boer War of 1899 to 1902, but in the course of the twentieth and twenty-first century this devastating war has also served as the creative stimulus for literary works in Dutch, Afrikaans, English and other languages. In this study, the focus falls on Afrikaans poems, plays, novels and short stories dealing with the war. The article

1 Prof. André Wessels is voorsitter van die departement Geskiedenis, Universiteit van die Vrystaat, Posbus 339, Bloemfontein, 9300. Telefoon: 051-4012488, faks: 051-4445803, epos-adres: wesselsa@ufs.ac.za). Die hulp en advies van mev. Leana Lategan, Eerste Museumgeesteswetenskaplike van die Nasionale Afrikaanse Letterkundemuseum en Navorsingsentrum (NALN) in Bloemfontein, word met groot dank erken. 
contends that, on the one hand, a literary text can sometimes capture the spirit and atmosphere of an event or period far better than a history book or article. On the other hand, knowledge of certain historical events and processes can sometimes be of great assistance in understanding and evaluating a literary work, be it a novel, short story, poem or play.

Special attention is paid to how the Anglo-Boer War is reflected in Afrikaans literature. Even while the war was still in progress, poems were being written in internment camps (the preferred description instead of the emotionally charged concentration camps) and prisoner-of-war camps. The Anglo-Boer War poems written by well-known poets such as Jan F.E. Celliers, Eugène Marais, C. Louis Leipoldt, Totius (J.D. du Toit) and D.J. Opperman deserve special mention.

Only a few Afrikaans plays with the Anglo-Boer War as theme have been written. Among those published are Eugène Marais's Nag: 'n drama in vier bedrywe (1937), Bartho Smit's Moeder Hanna (c.1957), Pieter Fourie's Die joiner (c.1976) and Reza de Wet's Nag, generaal (1991). Perhaps the most important (and in its time, most controversial) play in this regard is probably the well-known literary figure N.P. van Wyk Louw's Die pluimsaad waai ver of bitter begin (published in 1972), which dared to reconceptualise the Anglo-Boer War, broke with conventional stereotypes, and tackled sensitive issues head-on.

As far as novels are concerned, D.F. Malherbe's Vergeet nie: histories-romanties verhaal uit die Anglo-Boereoorlog (1913) is one of the earliest examples of a war novel in Afrikaans, while Gustav Preller's Oorlogsoormag en ander sketse en verhale (1923) is an example of a short story on the war, dating from the early 1920s. The 1930s saw an upsurge in Afrikaner nationalism, with a high point reached in 1938 with the Great Trek centenary. In light of the fact that the Anglo-Boer War is (together with the Great Trek) the most epoch-making event in the history of the Afrikaner people, it is hardly surprising that many Anglo-Boer War stories appeared in the popular Afrikaans magazine Die Huisgenoot during the 1930s and 1940s. Several new novels on the war were also published during this period, for example ' $n$ Wiel binne-in ' $n$ wiel by Miemie LouwTheron (1935), 'n Merk vir die eeue by T.C. Pienaar (1938) and Helkampe by Ewald Steenkamp (1941). During the Second World War, with its concomitant political tension in South Africa, the latter novel was banned by the government of J.C. Smuts (a famous former Boer general).

In due course, books on the Anglo-Boer War written for a younger generation also saw the light of day, for example Die ruiter in die nag by Mikro (C.H. Kühn) (1936), Boerseun, also by Mikro (1944) and Uit die puine by Sita (S.S. de Kock) (1952). In later years, books such as Ria Jordaan's Wynand se oorlog (1989) and Heléne le Roux's Eendag was daar 'n oorlog (1990) also appeared.

Etienne Leroux's Magersfontein, o Magersfontein! (1976) was an epoch-making new Afrikaans novel on the war. In the book the conflict is demythologised and the Afrikaner and his/her history satirised. It led to much controversy, but set the stage for a series of other novels that in due course also took an unabashedly critical look at the history of the war. In this regard, Elsa Joubert's Die reise van Isobelle (1995), Karel Schoeman's Verliesfontein (1998) and Christoffel Coetzee's Op soek na generaal Mannetjies Mentz (1998) are particularly noteworthy. Coetzee's disconcerting novel shattered what was left of the erstwhile idealised image of the Afrikaner's role during the war. The cruelty of the war has probably never been portrayed so explicitly and with such honesty as is the case in this novel.

The run-up to and centenary of the Anglo-Boer War also motivated several other authors to write novels and short stories based on events during the war. Examples are: 
Boereoorlogstories: 34 verhale uit die oorlog van 1899 tot 1902 (1998) and Charlotta (1999) by Jeanette Ferreira; Brandoffer (1998), a collection of short stories by Dolf van Niekerk; Groot duiwels dood (1998) by Eleanor Baker; and Buller se plan (1999) and Niggie (2002) by Ingrid Winterbach (who until c.1998 wrote under the pseudonym Lettie Viljoen). For Niggie, Winterbach was awarded the prestigious Afrikaans Hertzog Prize for Literature. P.G. du Plessis's magisterial Fees van die ongenooides (2008) followed later. In the meantime, A.H.M. Scholtz's Vatmaar (1995) and Afdraai: 'n kroniek van seermaak en seerkry, van vrede en verandering (1998), for the first time in a novel, viewed the war from a "coloured" person's perspective.

In stark contrast to the literary works of the 1930s and 1940s, when the so-called heroic dimension of the Anglo-Boer War was emphasised, war (and the Afrikaner's role in it) is seldom if ever glorified in modern literary texts. As a matter of fact, there is a concerted effort to deconstruct Afrikaner nationalism and everything with which it can be associated.

Some of the themes identified in the texts are the following: battles and other aspects of military conflict as, for example, portrayed in Magersfontein, o Magersfontein!; "heroes" as, for example, depicted in the Afrikaans translations of the books by the Dutchman Louwrens Penning (for example, Die leeu van Modderspruit (1966) and Die held van Spioenkop (1967)) and At van Wyk's Kniel, krygsman (1968), that explores the role played by General Christiaan de Wet; Cape Colony rebels, for example in Vuur op die horison by Engela van Rooyen (2000); and the role played by younger boys ("penkoppe") in the war, for example in Die penkopkommando by Fritz Steyn (1941), Boeta gaan op kommando by H.S. van Blerk (1977) and Die kwêrvoëlkommando: seuns wat manne was - 'n verhaal uit die Tweede Vryheidsoorlog by J.H. van Dyk (1988). The consequences of the British scorched-earth policy is investigated in, inter alia, Engela van Rooyen's Vuur op die borison.

Women play a central role in Afrikaans Anglo-Boer War fiction. J.R.L. van Bruggen's Die gerig (1943) was one of the first-ever feminist novels written in Afrikaans. Other examples are: Tuin van herinnering by H.S. van Blerk (1982) and Helena in die tyd van tente (1986). Prisoner-of-war camps form the historical background in P.J. Nienaber's Nag op St. Helena (1944); the role and experiences of black and coloured people are dealt with in Vatmaar and Afdraai by A.H.M. Scholtz; and relations between white, black and coloured are foregrounded in Moeder Poulin (1946) by G.H. Franz. Neglected themes include the following: hands-uppers, joiners and other traitors; "tragic figures" like General Piet Cronjé, who surrendered at Paardeberg on 27 February 1900 and ended up as a "circus artist" re-enacting the events in the United States of America; and the suffering of black and coloured people.

When a person decides to write a novel, short story, play or poem with the Anglo-Boer War as theme or background, certain historical facts must be kept in mind, for example: the David-Goliath nature of the conflict; the role played by many foreigners; the fact that it was neither a white man's war nor a gentleman's war; the terrible destruction wrought by the British scorched-earth policy; the trauma caused by the internment camp system and its effects on both white and black civilians (some 28000 white and at least 23000 black people died in camps); the atrocities committed by the Boers and the British; and the legacy of the war, which cast a shadow over the history of twentiethcentury South Africa.

In conclusion, the importance of historical knowledge for the analysis and interpretation of literary texts is emphasised. It is also postulated that novels and other literary works can play an important role in inculcating readers with a sense of history, thereby assisting 
them in giving account of their (controversial South African) past, including the history of the devastating and traumatic Anglo-Boer War of 1899 to 1902.

\section{Inleiding}

Die Anglo-Boereoorlog van 1899 tot 1902 het deur die jare heen nie net tot die skryf van baie geskiedenisboeke (waarskynlik reeds meer as 2700 ) en derduisende artikels in koerante en akademiese en ander tydskrifte anleiding gegee nie, maar ook in die letterkundes van verskeie tale neerslag gevind. Met verloop van tyd is talle nagraadse studies oor die oorlog en die Afrikaanse letterkunde voltooi, asook ander verwante studies wat vanuit ' $n$ literêre oogpunt aangepak is. Kyk in hierdie verband byvoorbeeld na die volgende: N.C. Lamprecht se Die aard van Afrikaanse outobiografiese geskrifte deur gevangenes en ballinge: die SuidAfrikaanse Oorlog (1899-1902) (M.A., Universiteit van Natal, Durban, 1993); J. Malan se Vroue-outobiografieë uit die Anglo-Boereoorlog-era: 'n literêrbistoriese ondersoek van enkele Afrikaanse en Nederlandstalige tekste (M.A., Nelson Mandela Metropolitaanse Universiteit, Port Elizabeth, 2005); en T.B. van der Walt se Die Anglo-Boereoorlog in Afrikaanse kinderboeke (D.Litt. et Phil., Rand Afrikaanse Universiteit, 2001).

Geskiedenis en die letterkunde gaan hand aan hand; trouens, kennis van en insig in die geskiedenis is soms ' $n$ voorwaarde vir die behoorlike bestudering van letterkunde, net soos die bestudering van letterkunde soms van veel nut kan wees by die bestudering van geskiedenis. Per slot van sake: deur middel van literêre werke word die leser in meer as een opsig "nader" aan die historiese gebeure gebring as deur bloot die kille feite te bestudeer; deur middel van letterkunde word die gees en atmosfeer van 'n bepaalde tydsgewrig beter vasgevang as in sommige (selfs baie?) geskiedenisboeke.

Aan die een kant is geskiedenis so 'n ernstige (belangrike) saak dat dit nie aan historici alleen oorgelaat kan word nie, en skrywers, digters en dramaturge het dus ook 'n rol te speel in die ontwikkeling van begrip vir ons verlede. Aan die ander kant is die letterkunde so 'n ernstige (belangrike) saak dat dit nie aan literatore alleen oorgelaat kan word nie, en gevolglik het historici ook'n rol te speel het in die kontekstualisering en verklaring van 'n bepaalde teks.

Die honderdjarige herdenking van die Anglo-Boereoorlog het tot 'n oplewing in die belangstelling in dié omstrede konflik gelei en boeke oor die oorlog (feite, fiksie en faksie) het vir'n tyd lank soos soetkoek verkoop. Vir meer as 'n eeu lank word die geskiedenis van die oorlog egter reeds as boustof of milieuskepper vir'n verskeidenheid literêre tekste gebruik.

Talle redes kan vir hierdie toedrag van sake aangevoer word. "Ellende, moord, oorlog daarsonder sou die wêreldletterkunde maar 'n skraal bestaan gevoer het." Die honderdjarige herdenking van die Anglo-Boereoorlog het ook daartoe gelei dat, enersyds, 'n hele rits nuwe boeke (romans) en veral kortverhale oor dié stryd die lig gesien het en, andersyds, dat talle van die groot aantal literêre werke wat in die loop van die twintigste eeu reeds verskyn het, weer afgestof en gelees is. "En dieselfde lesers wat met die hand op die Bybel (ewe vol bloedige verhale) hul teenkanting teen geweld sal verklaar, vind meestal niks lekkerder nie as om heerlik verskans in 'n gerieflike leunstoel self die vreeslikhede mee te maak."

2 W. van Zyl, "Klein kommando byeen vir bundel oorlogstories" (resensie oor J. Ferreira (red.), Boereoorlogstories: 34 verhale oor die oorlog van 1899-1902), Rapport, 18.4.1999, p. 16. 
Die doel van hierdie studie is om kortliks 'n oorsig te gee van die $20^{\text {ste }}$-eeuse literêre werke in Afrikaans wat die Anglo-Boereoorlog as tema het, nadat, in onderafdeling 2, gelet is op die historiese feite ten opsigte van die oorlog wat in dié letterkunde neerslag gevind het, en ten slotte enkele gevolgtrekkings te maak. Soos reeds hierbo aangedui, het die honderdjarige herdenking van die oorlog tot die publikasie van 'n hele aantal nuwe literêre tekste oor die oorlog gelei. Daar sal dus ook aangedui word in welke mate die oplewing in belangstelling in die skep van nuwe tekste teen ongeveer 2002 geëindig het, en of dit in die eerste dekade van die derde millennium voortgeduur het. Daar word egter deurgaans geensins op volledigheid aanspraak gemaak nie.

\section{Die geskiedenis wat die literêre tekste ten grondslag lê}

Die meeste Afrikaanse literêre werke wat oor die Anglo-Boereoorlog handel, getuig van goeie navorsing, maar weerspieël uiteraard nie noodwendig die volle historiese werklikheid nie. In die algemeen verwoord die fiksie wel die ryke verskeidenheid standpunte en benaderings ten opsigte van die geskiedenis van die oorlog. ${ }^{3}$ Die gevaar bestaan egter uiteraard steeds dat oorlog op een of ander wyse geromantiseer kan word, of dat die verskrikking van oorlog nie altyd volledig oorgedra word nie (of andersins melodramaties of oordrewe gekommunikeer word). Dit wil sê dat die leser deur fiksie oor die Anglo-Boereoorlog te lees, dus ook 'n geromantiseerde (of skeefgetrekte) beeld van dié oorlog kan bekom. Dit is ongelukkig so dat daar altyd diegene is wat alles wil reg-skiet. Ook sommige Afrikaners het steeds 'n oorgeromantiseerde beeld van die Anglo-Boereoorlog en gryp in sogenaamde "moeilike tye" terug na die geskiedenis van dié oorlog vir inspirasie. (Kyk byvoorbeeld na die "De la Rey"fenomeen na aanleiding van die opneem van dié populêre lied in Maart 2006.) ${ }^{4}$ Onnodig om te sê, interpreteer diesulkes die Anglo-Boereoorlog, soos ook die res van die Afrikaner se geskiedenis, soos dit hulle pas - gewoonlik deur'n bril wat erg polities gekleurd en uit fokus is. Daarenteen is daar ook dié literêre tekste wat effekberekend die geskiedenis skeeftrek, byvoorbeeld om te skok.

Daar moet natuurlik in gedagte gehou word dat die Anglo-Boereoorlog, saam met die Groot Trek van die 1830's, as die mees epogmakende gebeurtenis in die geskiedenis van die Afrikaner beskou kan word, en dus deur die jare heen 'n groot invloed op die psige van die Afrikaner en die ontwikkeling van Afrikanernasionalisme uitgeoefen het. Die oorlog het die beste en die slegste in die Afrikaner na vore gebring, want naas die selfopofferende en selfs heldhaftige optrede van sommiges, was daar ook die selfsugtige en lafhartige optrede van ander. Die oorlog het duidelik aangetoon dat die Afrikaner geen supermens of mitiese held was nie. Veral gedurende die eerste helfte van die twintigste eeu is die Boere in sommige geskiedenisboeke en literêre werke as onverskrokke volkshelde gekanoniseer. Die eensydige beklemtoning van die heroïese minderheidsgroep in Afrikanergeledere het deel van die Afrikaner se nasionalistiese mitologie geword, in belang van die Afrikaner se politieke aspirasies, iets wat met verloop van tyd die implementering van die beleid van apartheid

3 C. de Wet, "'n Verkennende studie van Anglo-Boereoorlog-fiksie", Acta Academica, 32(2), Augustus, 2000 , p. 58.

$4 \quad$ Kyk bv. http://www.bokvanblerk.co.za, geraadpleeg 29.11.2010; C. Steyn, "Songs about the AngloBoer War: past and present", Suid-Afrikaanse Tydskrif vir Kultuurgeskiedenis 21(2), November 2007, pp. 1-27. 
ingesluit het. Net soos daar veral vanaf die laat jare sestig van die vorige eeu op 'n meer kritiese wyse na die geskiedenis van die Afrikaner gekyk is, het die Sestigers ook op literêre gebied vernuwing gebring.

Geweld, van watter aard ook al, en dus ook in 'n sogenaamde "geregverdigde" oorlog, is altyd verskriklik. Die "probleem" met die Anglo-Boereoorlog is natuurlik dat dit in 'n sekere sin nie erg genoeg was nie. Miskien kon 'n gedig soos "Dulce et decorum est" van Wilfred Owen ${ }^{5}$ slegs uit die modder en bloed van Vlaandere en Frankryk tydens die Eerste Wêreldoorlog gebore word. Per slot van sake: tydens die eerste dag van die slag van die Somme op 1 Julie 1916 het ongeveer 19000 Britse soldate gesneuwel; dit wil sê sowat twee en 'n half keer meer as wat tydens die hele Anglo-Boereoorlog in die loop van 963 dae gesterf het. Die uiteindelike "butcher's bill", oftewel die totale getal ongevalle van die Eerste Wêreldoorlog, was meer as agt miljoen soldate dood en ongeveer nege miljoen burgerlikes dood. $\mathrm{Na}$ afloop van dié oorlog het nog ten minste twintig miljoen mense (en dalk soveel as 50 miljoen) wêreldwyd aan die sogenaamde Spaanse griep gesterf (1918-1919). ${ }^{6}$

Bogenoemde gegewens doen egter nie afbreuk aan die relatiewe verskrikking en ellende van die Anglo-Boereoorlog nie. Dié oorlog was die $226^{\text {ste }}$ van 230 koloniale oorloë (met inbegrip van strafekspedisies en ander kleiner veldtogte) waarin die Britse Ryk in die loop van koningin Victoria se 64-jaar lange bewind vanaf 1837 tot 1901 betrokke was. $^{7}$ Die AngloBoereoorlog was inderdaad die grootste en omvangrykste stryd in sy soort wat tot nog toe in suidelike Afrika gewoed het; dit was 'n regionale (bykans) algemene oorlog met kenmerke van 'n burgeroorlog en 'n totale oorlog. Die harde feite waarvan die skrywers van romans, dramas en kortverhale - ook vir vrouetydskrifte - moet kennis neem, is onder meer die volgende:

- Die blanke bevolking van wat vandag Suid-Afrika is, het op die vooraand van die Anglo-Boereoorlog op ongeveer 830000 te staan gekom het: 250000 "Afrikaanssprekendes" en 150000 Engelssprekendes in die Kaapkolonie, en onderskeidelik 10000 en 40000 in Natal, 148000 en 152000 in die Transvaal, en 71000 en 10000 in die Oranje-Vrystaat. Daar was 'n totaal van ongeveer 3,5 miljoen swart mense in die genoemde vier gebiede, asook ongeveer 300000 bruin mense en 100000 Asiërs. ${ }^{8}$

- Teenoor die totale "Afrikaanssprekende" blanke bevolking van die twee Boererepublieke van sowat 219000 het daar in 1899 in die Britse Ryk sowat 44 miljoen blankes gebly. ${ }^{9}$

5 E. Blunden (red.), The poems of Wilfred Owen (London, 1952), 1952), p. 66. Die titel bevat die eerste gedeelte van die Latynse uitdrukking "Dulce et decorum est pro patria mori", wat baie keer op oorlogsgedenktekens aangebring word, en beteken dat dit edel en paslik is om vir jou vaderland te sterf.

6 A.J.P. Taylor (hoofred.) en S.L. Mayer (samesteller), History of World War I (s.l., s.a.), p. 279; J.K. Taubenberger en D.M. Morens, "1918 influenza: the mother of all pandemics", Emerging Infections Diseases 12(1), Januarie 2006, pp. 15-22.

7 B. Farwell, Queen Victoria's little wars (London, 1973), pp. 364-371.

8 Kyk bv. Staats-almanak voor de Zuid-Afrikaansche Republiek (Pretoria, 1899) en The Natal almanac directory, and yearly register 1901 (Pietermaritzburg, 1901).

9 A. Wessels, Die Britse militêre strategie tydens die Anglo-Boereoorlog tot en met die Buller-fase (D.Phil., U.O.V.S., 1986), p. 370. 
- Ongeveer 32500 manlike persone tussen sestien en 60 jaar in die Zuid-Afrikaansche Republiek (ZAR, soos Transvaal destyds amptelik bekend gestaan het) en 22500 in die Oranje-Vrystaat was dienspligtig. ${ }^{10}$

- Uiteindelik het waarskynlik nie meer nie as ongeveer 79000 Transvalers, Vrystaters en hul bondgenote te velde geveg, maar op een slag waarskynlik nooit meer as ongeveer 47000 nie. $^{11}$

- Nie meer nie as ongeveer 15500 Kapenaars en ongeveer 500 Natallers het as rebelle aan die kant van die republikeine geveg, en van die wat gevang is, is 435 - heeltemal tereg - op grond van hoogverraad ter dood veroordeel. In die praktyk is die meeste egter deur lord Kitchener begenadig en dus is slegs 44 tereggestel. ${ }^{12}$

- Onder die bykans 3000 buitelanders wat aan Boerekant diens gedoen het, was daar naas 'n relatief groot aantal Nederlandssprekendes (naamlik 687, insluitende ten minste vyftien Belge) ook Franse (274), Duitsers (884), Iere (194; insluitende Iere vanuit die Verenigde State van Amerika, ander Amerikaners (64), Nore (31), Finne (25), Swede (109), Dene (39), Oostenrykers (28), Hongare (ses), Russe (55), 42 Russiese en ander Jode, Switsers (26), Italianers (119), een Spanjaard, een Bosniër, vier Portugese, twee Bulgare, veertien Grieke, een Algeryn, ten minste een Brasiliaan en een Chileen. ${ }^{13}$ Miskien kan die rol van buitelanders nog meer in die romanwêreld ontgin word.

- Teenoor die totale republikeinse leërs van ongeveer 78000 man (insluitende die ongeveer 16000 Kaapse en Natalse rebelle en 3000 buitelanders), het die Britse Leër in 1899 oor meer as 'n miljoen soldate beskik. ${ }^{14}$

- Die Britte het in totaal 448735 soldate in Suid-Afrika ontplooi ${ }^{15}$ - die meeste ooit in Mei 1901, toe daar ongeveer 250000 Britse soldate in Suid-Afrika was. ${ }^{16}$

- Sowel die Britte as die Boere het die stryd amptelik as 'n "witmansoorlog" beskou, maar in die praktyk het die Britte ten minste 140000 swart en bruin mense as bediendes, wa-drywers, touleiers, gewapende blokhuiswagte, gidse, spioene en ook as volwaardige soldate (as deel van kolonnes tydens die guerrilla-fase) aangewend, terwyl aan Boerekant ten minste 10000 swart mense as bediendes, wa-drywers, touleiers en

J.H. Breytenbach, Die geskiedenis van die Tweede Vryheidsoorlog in Suid-Afrika, 1899-1902 1 (Pretoria, 1978), p. 36.

A. Wessels, The Anglo-Boer War: white man's war, black man's war, traumatic war (Bloemfontein, 2011), p. 24.

G. Jordaan, Hoe zij stierven: mededelingen aangaande het einde dergenen aan wien gedurende den laatsten oorlog, in den Kaap-kolonie, het doodvonnis voltrokken is (Burgersdorp, s.a.) en J.H. Snyman, "Rebelle-verhoor in Kaapland gedurende die Tweede Vryheidsoorlog met spesiale verwysing na die militêre howe (1899-1902)", Argiefjaarboek vir Suid-Afrikaanse geskiedenis (Pretoria, 1962).

Kyk bv. E. Wessels, They fought on foreign soil (Bloemfontein, 2001).

Report of His Majesty's commissioners appointed to inquire into the military preparations and other matters connected with the war in South Africa (Cd. 1789, London, 1903), pp. 33-34. 
agterryers diens gedoen het - in enkele gevalle ook in 'n gewapende hoedanigheid. ${ }^{17}$ Hierdie is 'n aspek van die oorlog wat (verkieslik swart en bruin) skrywers nog veel meer kan benut.

- Die Britte het ongeveer 520000 perde en 150000 muile tydens die oorlog gebruik, waarvan ongeveer 350000 perde en 50000 muile gevrek het. Ongeveer 100000 van die Boere se perde het ook gevrek. ${ }^{18}$

- Die Britse Leër was aanvanklik nie gerat om die Boere in 'n uitgerekte oorlog te verslaan nie en die feit dat die Boere teen die einde van Maart 1900 tot guerrillaoorlogvoering oorgegaan het, het die Britte erge hoofbrekens besorg. Met verloop van tyd het die Britte 'n omvangryke teen-guerrillastrategie geïmplementeer wat onder meer die aanwending van al hoe meer swart en bruin mense ingesluit het, asook die oprigting van sowat 8000 blokhuise oor die lengte en breedte van Suid-Afrika ten einde die Boere se bewegingsvryheid aan bande te probeer lê, die gebruik van sogenaamde "flying columns" (dit wil sê vinnig-bewegende berede antikommandokolonnes), die gebruik van dryfjagte, die afbrand van Boereplase en dorpe, en die oprigting van interneringskampe. ${ }^{19}$

- Ongeveer 30000 Boere-plaashuise is opgeblaas of afgebrand, tesame met waarskynlik 100000 of meer wonings van swart plaasarbeiders. Talle landerye is verwoes, derduisende skape en beeste is doodgemaak of gebuit en meer as 40 dorpe is gedeeltelik of heeltemal verwoes. Hawelose wit en swart burgerlikes is na interneringskampe weggevoer. ${ }^{20}$ Die verwoesting van eiendom het beteken dat 'n groot volume erfstukke en ander kultuurgoedere, asook duisende boeke en dokumente, vernietig is.

- In totaal was daar in enige stadium ten minste 145000 blankes en 140000 swart mense in die interneringskampe, van wie ten minste 28000 blankes en ten minste 23000 (dalk selfs méér as 28 000) swart mense in die kampe gesterf het. Die meeste van die slagoffers was jonger as sestien jaar.

- Aan Britse kant het ten minste 7792 soldate gesneuwel of is aan hul wonde dood, 14658 is weens siekte dood of het verongeluk, en ongeveer 75000 is gewond of siek huis toe gestuur; ${ }^{21}$ terwyl 3990 Boere gesneuwel het, 924 weens siekte op kommando beswyk het, 157 in ongelukke omgekom het en 1118 in krygsgevangenekampe oorlede is. ${ }^{22}$ Daar bestaan geen volledige rekords oor hoeveel Boere gewond is, hoeveel swart en bruin mense aan Britse kant gesneuwel het of gewond is, of hoeveel swart persone op kommando gesterf het nie.

17 Kyk bv. Wessels, The Anglo-Boer War, pp. 97-134; P. Warwick, Black people and the South African War (Cambridge, 1983), pp. 4-5 en P. Labuschagne, Ghostriders of the Anglo-Boer War: the role and contribution of agterryers (Pretoria, 1999), passim.

18 Amery (red.), 6 (London, 1909), p. 417; F.J. van der Merwe, Horses of the Anglo-Boer War/Perde van die Anglo-Boereoorlog (Kleinmond, [2000]), passim.

19 Wat die Britte se teen-guerrilla-operasies betref, kyk bv. M.H. Grant, History of the war in South Africa 4 (London, 1910) en Amery (red.), 5.

20 S.B. Spies, Methods of barbarism? Roberts and Kitchener and civilians in the Boer republics January 1900May 1902 (Kaapstad, 1977) en F. Pretorius (red.), Verskroeide aarde (Kaapstad, 2001).

21 Amery (red.), 7 (London, 1909), p. 25.

22 F. Pretorius, The A to $Z$ of the Anglo-Boer War (Lanham, 2010), p. 80. 
- Sowel die Britse as Boeremagte het hul aan gruweldade (oorlogsmisdade) skuldig gemaak. Byvoorbeeld: die Boere het soms gewapende swart en bruin mense in Britse diens gevang en summier tereggestel. ${ }^{23}$

- Die oorlog het die Britse belastingbetaler meer as $£ 200000000$ uit die sak gejaag ${ }^{24}$ sowat R75 000000000 in hedendaagse terme. Dit is nie moontlik om te bepaal hoeveel die oorlog die Boererepublieke gekos het nie.

- Die oorlog het groot dele van Transvaal en die Vrystaat leeg en verwoes gelaat. Verder was daar 'n nalatenskap van haat en verbittering: tussen Afrikaans- en Engelssprekendes; binne Afrikanergeledere (veral tussen bittereinders en joiners) ${ }^{25}$ en tussen wit en swart. En dan was daar al die verwagtinge waaraan nie voldoen is nie. Die Britte het byvoorbeeld politieke regte aan swart mense belowe in ruil vir hulp teen die Boere, maar daar het niks van gekom nie. Dus kan die twintigste-eeuse geskiedenis van Suid-Afrika, in besonder die veelbewoë politieke geskiedenis van die land, nie begryp word sonder kennis en begrip van die Anglo-Boereoorlog nie. Trouens, daar kan 'n lyn getrek word vanaf dié oorlog tot by die stigting van die South African Native National Congress (SANNC) op 8 Januarie 1912 (vanaf 1923 bekend as die African National Congress, ANC) en verder tot by die regeringsverandering van 1994, terwyl die ontwikkeling van regse politieke groeperinge ook na die oorlog teruggespeur kan word.

- Alles in ag genome was die Anglo-Boereoorlog nie maar net nóg een van Brittanje se koloniale oorloë nie, maar die omvangrykste, duurste en veelseggendste oorlog waarby die Britse Ryk tussen die einde van die Napoleontiese Oorloë in 1815 en die uitbreek van die Eerste Wêreldoorlog in 1914 betrokke was. Vir die Afrikaner was dit 'n stryd met verreikende en traumatiese gevolge. ${ }^{26}$ Jan F.E. Celliers was die enigste vooraanstaande Afrikaanse digter wat die grootste deel van die oorlog op kommando diens gedoen het. ${ }^{27}$ Sy eenvoudige dog evokatiewe gedig "Dis al" uit sy bundel Die vlakte en ander gedigte (Pretoria: Volkstem, 1908) som waarskynlik die verskrikking en tragedie van oorlog (in die algemeen) beter op as talle ander tekste wat deur middel van eksplisiet-ontstellende beelde of beskrywings probeer om te skok. Ook vanuit 'n historiese oogpunt is dit 'n aangrypende en veelseggende gedig.

23 Kyk bv. Wessels, The Anglo-Boer War, pp. 123-126.

24 T. Pakenham, The Boer War (London, 1979), p. 572.

25 Kyk bv. A.M. Grundlingh, Die "hendsoppers" en "joiners": die rasionaal en verskynsel van verraad (Pretoria, 1999) en A. Blake, Boereverraaier: teregstellings tydens die Anglo-Boereoorlog (Kaapstad, 2010).

26 Kyk bv. A. Wessels, "Die traumatiese nalatenskap van die Anglo-Boereoorlog se konsentrasiekampe", Joernaal vir Eietydse Geskiedenis 26(2), Des. 2001, pp. 1-20.

27 Kyk A.G. Oberholster (red.), Oorlogsdagboek van Jan F.E. Celliers 1899-1902 (Pretoria, 1978).

Td, 7(2), Desember 2011, pp. 185- 204. 


\section{3. 'n Oorsig van die Afrikaanse letterkunde oor die Anglo-Boereoorlog 28}

Wanneer daar gelet word op die invloed wat die Anglo-Boereoorlog op letterkunde gehad het, moet streng gesproke ook na die Engelse, ${ }^{29}$ Nederlandse $^{30}$ en talle ander Europese letterkundes ${ }^{31}$ gekyk word. Al dié letterkundes val egter buite die bestek van hierdie studie en daar word dus hier slegs op die "suiwer" Afrikaanse letterkunde gelet. Hoewel die klem op die formele Afrikaanse letterkunde val, sal daar soms ook na populêre romans verwys word. Die oorsig wat nou volg, is alles behalwe volledig en wil bloot 'n voëlvlug verskaf oor 'n omvangryke tema. Teen 1984 is immers reeds meer as 350 romans wat teen die agtergrond van die Anglo-Boereoorlog afspeel ${ }^{32}$ in talle tale gepubliseer, en in een jaar, 1998, het 'n enkele uitgewer meer as 60 manuskripte ontvang wat oor die oorlog handel. ${ }^{33}$

\subsection{Digkuns en dramas}

Die Afrikaanse poësie is deur die jare heen deur die Anglo-Boereoorlog beïnvloed; trouens, reeds tydens die oorlog is ' $n$ groot aantal gedigte in internerings- ${ }^{34}$ en krygsgevangenekampe geskryf, waarin onder meer aan die smart en ellende van oorlog en die bittere vernedering

28 Kyk in die algemeen bv. E. Swanepoel, "Waarheid en versoening: representasies van die SuidAfrikaanse Oorlog (1899-1902) in Afrikaanse, Engelse en Nederlandse fiksie", Stilet 10(2), 1998, pp. 63-75; K. du Pisani, "Fact and fiction: representations of the South African War in Afrikaans history writing and literature", New Contree 44, Sept. 1999, pp. 164-184; De Wet, pp. 38-65; C.N. van der Merwe, "Presentations of war in Afrikaans fiction", Stilet 13(2), Junie 2001, pp. 65-78; H.P. van Coller, "1998-2000: skrywers op die tweesprong - prosakroniek", Tydskrif vir Geesteswetenskappe 42(4), Desember 2002, pp. 304-320.

29 Kyk bv. M. van Wyk Smith, Drummer Hodge: the poetry of the Anglo-Boer War (1899-1902) (Pretoria, 1999), passim; M. van Wyk Smith, "The poetry of the war" in P. Warwick (red.), The South African War: the Anglo-Boer War 1899-1902 (Harlow, 1980), pp. 292-314; B.F. Gasser, A study of the response of English poets to the South African War of 1899-1902 (D.Phil., University of Oxford, 1979), passim; V.B. Hein, British literary figures and the Boer War (M.A., Georgia State University, Atlanta, 1971), passim; J. McDonald, The Boer War in English fiction (M.A., University of Columbia, New York, 1940), passim; D.J. Weinstock, The Boer War in the novel in English, 1884-1966: a descriptive and critical biography (Ph.D., University of California, Los Angeles, 1968).

30 Kyk bv. J. van der Elst, "Die Anglo-Boereoorlog: 'n vertekende beeld vanuit die verlede", Literator 20(30), Nov. 1999, pp. 147-160; W. Jonckheere, Nasie en mite: Nederland en die Anglo-Boereoorlog (D.F. Malherbe-gedenklesing 18, Acta Varia 1, 1999); H. Ester, "Met Penning naar Zuid-Afrika", Zuid-Afrika 76(8), Aug. 1999, pp. 112-113.

31 Kyk bv. G. Teulié, La guerre des Boers et let images de l'Afrique du Sud: iconographie, littérature et récits analyse de l'origine des systèmes de représentation et des mentalités en présence (Ph.D., Universiteit van Paul Válery, Montpellier III, 1999).

32 S. Gray, "Introduction" in D. Blackburn, A burgher Quixote (Kaapstad, 1984), p. xvii. Blackburn se boek het oorspronklik in 1903 verskyn.

33 A.P. Brink, "Anglo-Boer War spawns milestones in new fiction”, The Sunday Independent, 22.8.1998, p. 19.

34 Die meer neutrale term interneringskamp word bo die emosioneel en histories gelaaide term konsentrasiekamp verkies ten einde 'n duidelike onderskeid tussen die Britse kampe vir Boere en swart burgerlikes in die Anglo-Boereoorlog en Nazi-kampe vir Jode en andere in die Tweede Wêreldoorlog te tref. 
uitdrukking gegee is. Kyk in hierdie verband byvoorbeeld na F.W. Reitz se Oorlogs en ander gedigte (Potchefstroom: Het Westen-Drukkerij, 1910). Die meeste van hierdie gedigte was weliswaar geen literêre meesterstukke nie, maar naas die terapeutiese waarde wat die skryf daarvan waarskynlik gehad het, het dit tog tegelyk ook die grondslag/vertrekpunt gevorm vir baie ander - en beter - pennevrugte. Met verloop van tyd het die oorlogs- en ander gedigte van Jan F.E. Celliers, Eugène Marais, C. Louis Leipoldt en Totius (J.D. du Toit) die Afrikaanse poësie laat uitstyg bo blote rymelary en epiese ballades. Kyk in hierdie verband byvoorbeeld na Celliers se "Die kampsuster" en "Blomme", Marais se "Winternag", "Die oorwinnaars" en "1902", Leipoldt se "Vandag" en "Aan 'n seepkissie", en Totius se "Mei 1900", "Kindergraffies" en "Vergewe en vergeet" digter se bundel Bij de monument (Potchefstroom: Koomans, 1917). Leipoldt was tydens die oorlog die redakteur van die South African News in Kaapstad en het rebelleverhore in OosKaapland bygewoon. In sy dramatiese monoloog "Oom Gert vertel" word die morele dilemma waarin baie Kaapse Afrikaners hul bevind het, uitgebeeld: die feitlik onmoontlike keuse tussen lojaliteit aan hul wettige regering of steun aan hul taalgenote en soms bloedverwante. ${ }^{36} \mathrm{Nog}$ later is ook die literêre reus D.J. Opperman deur die AngloBoereoorlog geïnspireer. Kyk byvoorbeeld na sy "Gebed om die gebeente", wat oor Gideon Scheepers handel. ${ }^{37} \mathrm{Hy}$ het egter krities gekyk na die rol van die Afrikaner in die moderne wêreld. ${ }^{38}$

Tot dusver is relatief min Afrikaanse dramas geskryf wat teen die agtergrond van die AngloBoereoorlog afspeel. Voorbeelde sluit die volgende in: Horatius (vermoedelik die skuilnaam van I.G. Horak) se Mag is reg: treurspel vir die Boere-oorlog in vier bedrijwe (Kaapstad: Nasionale Pers Boekhandel, 1917); D.C. Postma se histories-simboliese drama Oom Paul: 'n simboliese drama in drie bedrywe (Bloemfontein: Nasionale Pers, 1944); Eugène Marais se Nag: 'n drama in vier bedrywe (Pretoria: J.L. van Schaik, 1937); Bartho Smit se Moeder Hanna (Johannesburg: Afrikaanse Pers-Boekhandel, ca. 1957); N.P. van Wyk Louw, Die pluimsaad waai ver of bitter begin (Kaapstad: Human \& Rousseau, 1972); Pieter Fourie se Die joiner (Kaapstad: Tafelberg, ca. 1976); en Reza de Wet se Nag, generaal (gepubliseer in Vrystaattrilogie, Pretoria: HAUM-Literêr, 1991). Louw se Pluimsaad het tot heelwat omstredenheid aanleiding gegee en het 'n belangrike rol gespeel in die herkonseptualisering van die AngloBoereoorlog deurdat netelige kwessies soos tweedrag in Afrikanergeledere (bittereinder vs joiner) en die morele regverdiging al dan nie van die oorlog aan die orde gestel is - iets wat tydens die hoogbloei van Afrikanernasionalisme ondenkbaar was. ${ }^{39}$ Let verder ook op Chris

35 Wat betref die tekste van die gedigte waarna verwys is, kyk bv. E. Jansen en W. Jonckheere (samestellers), Boer en Brit: Afrikaanse en Nederlandse tekste uit en om die Anglo-Boereoorlog (Pretoria, 1999), pp. 87-88, 125, 175, 228-231, 239-240, 260, 302-303, 337-338.

36 Vir die teks van "Oom Gert vertel", kyk bv. Leipoldt se Versamelde gedigte (Kaapstad, 1980), pp. 5-11 en Jansen en Jonckheere (samestellers), pp. 325-334. Kyk ook H. Viljoen, "What Oom Gert does not tell: silences and resonances of C. Louis Leipoldt's 'Oom Gert vertel'”, Literator 20(3), Nov. 1999, pp. 129-146.

37 Jansen en Jonckheere (samestellers), pp. 293-295.

38 E. Jansen, "De oorlog en de Afrikaanse literatuur", Zuid-Afrika 76(8), Aug. 1999, pp. 110-111.

39 Kyk in die algemeen K. du Pisani, "Volkshelde': die Boerekrygerbeeld en die konstruksie van Afrikaner-nasionalisme”, Literator 20(3), Nov. 1999, pp. 87-112; K. du Pisani, "Wat is 'n held?: herkonseptualisering van die Boerekrygerbeeld na 1961", Joernaal vir Eietydse Geskiedenis 25(1), Junie 2000 , pp. $42-55$.

Td, 7(2), Desember 2011, pp. 185- 204. 
Vorster se Kwaggapolitiek (onder meer in 2000 by die Aardklop-kunstefees te Potchefstroom en in 2001 by die Klein-Karoo Nasionale Kunstefees te Oudtshoorn opgevoer), wat onder andere besin oor die vraag of dit enigsins sinvol is om 'n stuk óór die Anglo-Boereoorlog op te voer.

\subsection{Romans en kortverhale}

In die lig van die dramatiese aard van 'n stryd soos die Anglo-Boereoorlog is dit vanselfsprekend dat skrywers dié konflik as inspirasie sal gebruik om tekste te skep. Skrywers kan uiteraard ryklik put uit die magdom egodokumente wat uit die oorlog voortgevloei het, met ander woorde die dagboeke en herinneringsgeskrifte wat nagelaat is deur mans op kommando of vrouens in die kampe. Dié tipe tekste sluit in alles van genl. Christiaan de Wet se De strijd tusschen Boer en Brit (Amsterdam: Hiveker \& Wormser, 1902) en Deneys Reitz se Commando: a Boer journal of the Boer War (London: Faber \& Faber, 1929) tot minder bekende persone soos kmdt. Japie Neser se oorlogsherinneringe, ${ }^{40}$ en verder Hendrina Rabie-Van der Merwe se Onthou! In die skaduwee van die galg (Bloemfontein: Nasionale Pers, 1940) en A. Badenhorst se Tant Alie van Transvaal (Afrikaanse vertaling, Kaapstad: Nasionale Pers, 1939).

Nogtans was daar anvanklik min romans met die oorlog as agtergrond, moontlik omdat baie mense gevoel het dat dit verdere verdeeldheid in Afrikanergeledere kon veroorsaak. Kyk in hierdie verband na die diskoers oor "onthou" en/of "vergewe en vergeet"; oftewel (in postapartheidterme) "waarheid" en/of "versoening". ${ }^{41}$ Sommige mense wou (en wil steeds) nou maar eerder die verlede vergeet - asof dit enigsins moontlik is. Tekste van belang oor die bogenoemde diskoers is onder meer Gustav Preller se Oorlogsoormag en ander sketse en verbale (Kaapstad: Nasionale Pers, 1923) en D.F. Malherbe se roman Vergeet nie: histories-romanties verhaal uit die Anglo-Boereoorlog (Potchefstroom: Het Westen-Drukkerij, 1913). In laasgenoemde boek beklemtoon Malherbe die Afrikaners se gemeenskaplike verlede as bindende faktor en word alles in die werk gestel om die Afrikaner se groepsidentiteit lewend te hou. ${ }^{42}$

In die dertigerjare van die vorige eeu was daar'n oplewing in Afrikaner-nasionalisme. Geen wonder nie dat talle verhale oor die Anglo-Boereoorlog in die gesinstydskrif Die Huisgenoot gepubliseer is en dat talle oorlogsromans verskyn het, byvoorbeeld Miemie-Louw Theron se 'n Wiel binne-in 'n wiel (Kaapstad: Nasionale Pers, 1935), N.J. van der Merwe se Die burgemeester van Sannaspos (Bloemfontein: Nasionale Pers, 1929), T.C. Pienaar se 'n Merk vir die eeue (Bloemfontein: Nasionale Pers, 1938) en J.R.L. (“Kleinjan”) van Bruggen se Bittereinders (Potchefstroom: H.W. Huyser, 1935). Laasgenoemde is gebaseer op die herinneringe van sowat 40 vroue wat in die interneringskamp te Mafeking aangehou is en kan as 'n vroeë voorbeeld van "faksie" (faction) in die Afrikaanse letterkunde beskou word. In hierdie tipe oorlogsromans is die stereotipe beelde van die goeie, heldhaftige bittereinder en slegte, lafhartige joiner beklemtoon. Ietwat later verskyn Ewald Steenkamp se Helkampe

40 Kyk A. Wessels (red.), "Die oorlogsherinneringe van kommandant Jacob Petrus Neser”, Christiaan de Wet-annale 7, Okt. 1987, pp. 1-134.

41 Kyk bv. H.P. van Coller, "Die waarheidskommissie in die Afrikaanse letterkunde: die Afrikaanse prosa in die jare negentig”, Stilet 9(2), 1997, pp. 9-21.

42 C.N. van der Merwe, "Verhale oor die Anglo-Boereoorlog”, Literator 19(3), Nov. 1997, pp. 87-88. 
(Johannesburg: Voortrekkerpers, 1941), wat deur die regering van J.C. Smuts (die voormalige befaamde Boeregeneraal) verbied is in die lig van die Tweede Wêreldoorlog wat toe gewoed het. Gegewe die historiese feit dat die Boere 'n klein minderheid teenoor die magtige Britse Ryk was, is die grondslag vir die mitologisering van die Afrikaner se vryheidstryd gelê. Let verder ook op 'n belangwekkende teks soos J.R.L. van Bruggen se Die gerig (Pretoria: UnieBoekhandel, 1943). ${ }^{43}$

Wat jeugverhale betref, is daar onder meer Mikro (skuilnaam van C.H. Kühn) se Die Bont Takbok-reeks van drie boeke wat oorspronklik in die laat 1940's verskyn het, naamlik Die Bont Takbok (Johannesburg: Nasionale Boekhandel, 1957), Die Bont Takbok verken (Kaapstad: Tafelberg, 1971) en Die Bont Takbok word bittereinder (Johannesburg: Nasionale Boekhandel, 1958). In 1936 verskyn Mikro se Die ruiter in die nag (Bloemfontein: Nasionale Pers, 1936). Verder was daar ook nog Mikro se ander jeugverhale soos Burgers van die Kleingeld-kommando (Pretoria: J.L. van Schaik, 1958), Die jongste veldkornet (Kaapstad: Simondium-uitgewers, 1964), Die jongste ruiter (Kaapstad: Nasionale Boekhandel, s.a.), Kaptein Gereke (Bloemfontein: Nasionale Pers, 1937) en Boerseun (Bloemfontein: Nasionale Pers, 1944). Let verder ook op Nicolaas Hofmeyr se Fanie:'n storie van vriendskap en liefde en avonture met'n stukkie gouddraad uit ons heldetyd saamgevleg (Kaapstad: Nasionale Pers Boekhandel, 1925), Rudolf Meiring (skuilnaam van S. Ign. Mocke) se Groter liefde: 'n roman uit die Driejarige Oorlog (Bloemfontein: Nasionale Pers Boekhandel, 1945) en Sita (skuilnaam van S.S. de Kock) se Uit die puine (Johannesburg: Dagbreek-Boekhandel, 1952). In hierdie boeke, soos ook in H.S. van Blerk se Tuin van herinnering (Kaapstad: Tafelberg, 1982), word die oorlog "tradisioneel" benader. Dit word met ander woorde hoofsaaklik vanuit Afrikaneroogpunt geskryf: die Afrikaner se lyding en ontbering word beklemtoon en 'n boodskap van nasietrots en behoudendheid word uitgedra. Let verder ook op Nan Lubbe se jeugverhaal Die jongste spioen (Kaapstad: Tafelberg, 1969), Maretha Maartens se Gezina en die bruin wind, Franci Greyling se Helena in die tyd van die tente en Dirkie, Drieka, Frederika (Kaapstad: Tafelberg, 1988), Ria Jordaan se Wynand se oorlog (Kaapstad: Tafelberg, 1989) en Heléne le Roux se Eendag was daar 'n oorlog (Kaapstad: Tafelberg, 1990). ${ }^{44}$

Met verloop van tyd het daar ook meer "volwasse" romans en ander tekste verskyn met die Anglo-Boereoorlog as tema, byvoorbeeld Etienne Leroux se omstrede dog bakenverskuiwende en konvensieverbrekende roman Magersfontein, o Magersfontein! (Kaapstad: Human \& Rousseau, 1976), waarin daar by wyse van spreke deur die "derde oog" op 'n satiriese en ironiese wyse na die historiese gegewens gekyk word. ${ }^{45}$ Die geskiedenis word gedemitologiseer en Afrikanernasionalisme gesatiriseer.

Die Anglo-Boereoorlog hoef nie op 'n heroïese vlak aangepak te word nie, soos bewys is deur Annico van Vuuren se roman Splinters van spieel en klip (Kaapstad: Tafelberg, 1993), "waarin

44 Kyk bv. T. van der Walt en M. Nieman, "Vrouejeugboekskrywers oor die Anglo-Boereoorlog: realisme en versoening na dekades van avontuur en nasionalisme", Tydskrif vir Geesteswetenskappe 49(4), Desember 2009, pp. 674-687.

Kyk bv. M.J. Prins, "Postmodernistiese tendense in Magersfontein, o Magersfontein! deur Etienne Leroux", Literator 19(3), November 1998, pp. 99-117; T. de Wilde, "Etienne Leroux se ontmitologisering van Magersfontein", Stilet 1(2), Julie 1989, pp. 57-65. Kyk ook S.L. Barnard, "Die geskiedskrywer en die romanskrywer: 'n interpretasie van enkele 'historiese' feite in Magersfontein, o Magersfontein!", Acta Academica 21(1), 1989, pp. 15-29. 
die temas van liefde, dood en verraad in 'n gewone man se lewe op eksistensiële vlak ondersoek word, en die oorlog 'n geluid van verre donder bly". ${ }^{46} \mathrm{Kyk}$ in hierdie verband ook na Karel Schoeman se Veldslag: twee novelles (Kaapstad: Human \& Rousseau, 1971).

In die loop van die 1990's het 'n hele aantal ander indrukwekkende oorlogsromans verskyn, byvoorbeeld Lettie Viljoen (skuilnaam van Ingrid Winterbach) se Belemmering (Bramley: Taurus, 1990), Elsa Joubert se magistrale werk Die reise van Isobelle (Kaapstad: Tafelberg, 1995) en Marlise Joubert se Oranje Meraai (Kaapstad: Tafelberg, 1996). En dan, uiteraard, is daar Christoffel Coetzee se Op soek na generaal Mannetjies Mentz (Kaapstad: Queillerie, 1998). Coetzee dwing die leser om na sy eie, en elke mens, se boosheid te kyk en van sy of haar gebrokenheid rekenskap te gee. Mannetjies Mentz (dit wil sê Man, Mens, Everyman, Elkerlijk) word immers 'n allegoriese persona vir Afrikanermanlikheid en van menswees in die algemeen. ${ }^{47}$ Saam met talle ander literêre werke van die 1990's dra Coetzee se roman by tot die vernietiging van die geïdealiseerde beeld van die Afrikaner tydens die AngloBoereoorlog.

Op soek na generaal Mannetjies Mentz is natuurlik, soos talle ander fiksieverhale, 'n alternatiewe "geskiedenis" van die oorlog, 'n stuk gefabriseerde en ondermynende "geskiedenis". Dit is 'n skyngeskiedenis en 'n halwe waarheid (deels feite, deels fiksie); reguit gestel is dit 'n (moedswillig) "geliegde geskiedenis" en (histories gesproke) dus in 'n groot mate 'n bedrogspul. Maar al is baie van die gegewens fiktief, en al ondergrawe Coetzee die tradisionele historikus deur te twyfel of die geskiedenis die volle waarheid omtrent die verlede kan meedeel, ${ }^{48}$ is die wreedheid van oorlog waarskynlik nog nooit tevore só eksplisiet en eerlik in Afrikaans verwoord as juis in Coetzee se roman nie. ${ }^{49}$ Coetzee se roman beklemtoon die waarde van sowel die letterkunde as die geskiedenis en dwing die leser om met nuwe oë na die geskiedenis van die Anglo-Boereoorlog te kyk.

Ander noemenswaardige prosawerke van die 1990's is onder meer Jeanette Ferreira se populêre roman-drieluik oor die oorlog, naamlik Babette (Johannesburg: Perskor, 1995), Catharina (Kaapstad: Human \& Rousseau, 1996) en Charlotta (Kaapstad: Human \& Rousseau, 1999), asook haar bundel Boereoorlogstories: 34 verhale uit die oorlog van 1899-1902 (Pretoria: Van Schaik, 1998). ${ }^{50}$ Verder was daar ook die kortverhaalbundel van Dolf van Niekerk, Brandoffer (Kaapstad: Tafelberg, 1998) en Eleanor Baker se Groot duiwels dood (Kaapstad: Human \& Rousseau, 1998), 'n middelmootteks wat vir ontspanning gelees wil word, maar nogtans die eietydse sosiopolitieke kwessies verreken. Kyk verder ook na Lindeque de Beer (samesteller) se Vuur! Verhale oor die Vryheidsoorlog 1899-1902 (Pretoria: J.P. van der Walt, 1999), en Lettie Viljoen (tot ongeveer 1998 die skuilnaam van Ingrid

46 Petra Müller se resensie in Die Burger, 29.6.1993, p. 8.

47 Kyk bv. L. Renders, "Tot in die hart van die boosheid: twee resente Afrikaanse romans oor die AngloBoereoorlog”, Literator 20(3), Nov. 1999, pp. 113-121, 126-127.

48 A. Nel, "Kragtige debuutroman wat meesleurend lees”, Beeld, 11.5.1998, p. 8.

49 Kyk in die algemeen ook J. Moon, Die verhouding tussen geskiedenis en literatuur in post-apartheid SuidAfrika, met spesifieke verwysing na Verliesfontein deur Karel Schoeman en Op soek na generaal Mannetjies Mentz deur Christoffel Coetzee (M.A., Stellenbosch Universiteit, 2003).

50 Vir 'n indringende bespreking van bg., kyk bv. H. du Plooy, “Die deurlopende koord”, Literator 20(3), Nov. 1999, pp. 201-212. 
Winterbach) se Karolina Ferreira (Kaapstad: Human \& Rousseau, 1993), Buller se plan (Kaapstad: Human \& Rousseau, 1999) en Niggie (Kaapstad: Human \& Rousseau, 2002).

Verder verdien Karel Schoeman se Verliesfontein (Kaapstad: Human \& Rousseau, 1998) ook vermelding. Dit is 'n merkwaardige boek waarin die grense van sowel die historiese roman as van die geskiedskrywing opgehef word en daar tot beter begrip van die verlede gekom word. ${ }^{51}$ Die boodskap in Schoeman se boek is duidelik: wie die verlede vergeet, is gedoem om dit te herlewe. En dan is daar die uitmuntende werke van Klaas Steytler, Ons oorlog (Kaapstad: Tafelberg, 2001) en van P.G. du Plessis, Fees van die ongenooides (Kaapstad: Tafelberg, 2008).

Van besondere belang is ook die "bruin" skrywer A.H.M. Scholtz se romans Vatmaar (Kaapstad: Kwela, 1995) en Afdraai: 'n kroniek van seermaak en seerkry, van vrede en verandering (Kaapstad: Kwela, 1998), waarin die oorlog vir die eerste keer (in die literatuur) vanuit 'n swart of bruin persoon se oogpunt in Afrikaans belig word. Die hoop word uitgespreek dat nog meer sulke tekste, soos ook kortverhale, gedigte en dramas, deur bruin en hopelik selfs swart Suid-Afrikaners - in Afrikaans sal verskyn. ${ }^{52}$

Tydens die Anglo-Boereoorlog het die Afrikanervrou 'n tragies-heroïese rol gespeel. Dít het daartoe gelei dat sy daarna op 'n meer respekvolle wyse in die Afrikaanse letterkunde uitgebeeld sou word en dat die eerste Afrikaanse vroueskrywers ook na vore sou tree. Tot en met 1900 is vroue deur die Genootskap van Regte Afrikaners verbied om aan die Eerste Taalbeweging deel te neem. Na die oorlog het talle vroue egter hul kampervaringe te boek gestel. Net so het talle vroulike joernaliste en skrywers hul stempel afgedruk..$^{53}$

Anders as in literêre werke van veral die 1930's en 1940's waarin die heroïese sy van die Anglo-Boereoorlog in die algemeen beklemtoon is en die tekste baie keer niks anders was nie as (suksesvolle) pogings om Afrikanernasionalisme te bevorder, word die oorlog (en die Afrikaner) selde in die moderne tekste verheerlik; trouens, 'n mens sou tot die gevolgtrekking kon kom dat daar doelbewus' $n$ poging is om Afrikanernasionalisme af te wys. ${ }^{54}$

Die vraag kan egter gevra word of daar nie sedert ongeveer 1998, wat betref effekberekende herdenkingsgerigte literêre werke oor die oorlog, sprake van 'n "handige omgaan met die laat $20^{\text {ste }}$ eeuse kunsgrepe, die te bewuste geskryf an kunsprosa" is nie. "By die oordra van die oorlogservaring bly die vroeëre pretensieloser werke deur mense wat wel deel was van die stryd", waarskynlik veel meer effektiewer. ${ }^{55}$

51 G.J. Schutte, “Verliesfontein: lesvoorbeeld voor historici”, Zuid-Afrika 76(8), Aug. 1999, p. 114. Kyk ook Renders, pp. 121-127. Kyk ook die M.A.-verhandeling van J. Moon waarna reeds in voetnoot 49 hierbo verwys is.

52 Jansen, p. 111.

53 E. Britz, "Die Afrikaanse vroue het eers begin skryf na loutering van konsentrasiekampe", Die Burger, 4.2.1999, p. 11.

54 Jansen, p. 110.

55 W. van Zyl, "Klein kommando byeen vir bundel oorlogstories" (resensie oor J. Ferreira (red.), Boereoorlog-stories: 34 verhale oor die oorlog van 1899-1902), Rapport, 18.4.1999, p. 16. 
Al die genoemde tekste soek egter op hul eie manier 'n bepaalde waarheid - 'n literêre waarheid, soms ook 'n historiese waarheid, maar altyd 'n waarheid oor die kern van menswees. Tydens die betekenisvolle oorgangsfase wat om en by die millennium-wending in Suid-Afrika beleef is, was dit logies dat mense bestek sou opneem om sin te probeer maak van alles wat om hul gebeur het en wat hul ervaar het. Dit het hulle gedoen deur terug te kyk op die verlede ten einde die toekoms met beter begrip en selfvertroue tegemoet te gaan. Die bande met die verlede ('n verlede wat onder meer die Anglo-Boereoorlog, die Eerste Wêreldoorlog, kommunisme, Naziïsme, die Tweede Wêreldoorlog, die oorlog in Viëtnam, apartheid, die Koue Oorlog en die dramatiese beëindiging daarvan, die gebeure van 11 September 2001, die tegnologiese ontploffing en toenemende globalisering insluit) is tegelyk knellende bande en ankertoue.

\subsection{Temas wat angesny word}

Wanneer daar na die groeiende volume letterkunde oor die Anglo-Boereoorlog gekyk word, ontstaan die vraag: Watter tipe sake leen hul tot die skryf van fiksie oor die oorlog? Watter invalshoeke is daar? Die volgende is van die temas wat onderskei kan word:

- Veldslae en ander aspekte rakende die militêre verloop van die oorlog, byvoorbeeld Etienne Leroux se Magersfontein, o Magersfontein! en Karel Schoeman se Verliesfontein.

- "Helde", byvoorbeeld Christiaan de Wet en Danie Theron. Kyk byvoorbeeld na Louwrens Penning se oorlogsromans oorspronklik in Nederlands geskryf, maar later deur Chris Barnard in Afrikaans vertaal en gepubliseer, naamlik Die leeu van Modderspruit (Pretoria: J.L. van Schaik, 1966), Die held van Spioenkop (Pretoria: J.L. van Schaik, 1967), Die verkenner van Christiaan de Wet (Pretoria: J.L. van Schaik, 1967), Die oorwinnaar van Nooitgedacht (Pretoria: J.L. van Schaik, 1967) en Die kolonis van Suid-wes Afrika (Pretoria: J.L. van Schaik, 1967). Kyk ook na At van Wyk se Kniel, krygsman (Kaapstad: Buren-uitgewers, 1968), 'n historiese roman oor De Wet. Verder is daar die tekste wat oor pres. Paul Kruger handel, byvoorbeeld D.C. Postma se Oom Paul: 'n simboliese drama in drie bedrywe en Anna M. Louw se roman Die groot gryse (Kaapstad: Tafelberg, 1968). In Mikro se jeugverhaal Vlam (Kaapstad: Human \& Rousseau, 1970) is die perd met die titelnaam die held. Minder waarskynlike helde kom voor in A.H.M. Scholtz se Vatmaar en Afdraai, terwyl Christoffel Coetzee se Mannetjies Mentz-karakter'n omstrede heldefiguur is.

- "Skurke", byvoorbeeld Joseph Chamberlain en lord Kitchener; en natuurlik die hendsoppers en veral die joiners. Hierdie is 'n tema wat nog nie werklik na behore in die Afrikaanse letterkunde ontgin is nie.

- Tragiese figure, byvoorbeeld genl. Piet Cronjé wat te Paardeberg oorgegee het, daarna na St. Helena as krygsgevangene weggevoer is, en na afloop van die oorlog as 'n tipe "sirkus-akteur" in Anglo-Boereoorlogvoorstellings in die Verenigde State van Amerika opgetree het. ${ }^{56} \mathrm{Kyk}$ in hierdie verband Sonja Loots se Sirkusboere (Kaapstad: Tafelberg, 2011).

- Rebelle, byvoorbeeld in Karel Schoeman se Verliesfontein, Engela van Rooyen se Vuur op die horison (Kaapstad: Tafelberg, 2000) en Adriaan Roodt se Die Kaapse rebel: die

56 F.J.G. van der Merwe, "Die 'Boeresirkus' van St. Louis, V.S.A. (1904)", Suid-Afrikaanse Tydskrif vir Kultuurgeskiedenis 12(2), November 1998, pp. 85-99. 
oorlogsavonture van kommandant Edwin Conroy tydens die Tweede Vryheidsoorlog (Pretoria: J.P. van der Walt, 1998). Laasgenoemde is 'n roman wat op historiese feite gebaseer is.

- Penkoppe, byvoorbeeld in Mikro se Die jongste ruiter (Kaapstad: Nasionale Boekhandel, 1954), Fritz Steyn se Die penkopkommando (Johannesburg: Voortrekker Pers, 1941), J.H. van Dyk se Die kwêvoëlkommando: seuns wat manne was - 'n verhaal uit die Tweede Vryheidsoorlog (Morgenzon: Oranjewerkers Promosies, 1988) en H.S. van Blerk se Boeta gaan op kommando (Pretoria: J.P. van der Walt, 1977).

- Die verskroeide aarde-beleid, byvoorbeeld in Engela van Rooyen se Vuur op die horison (Kaapstad: Tafelberg, 2000).

- Vrouens en kinders in interneringskampe - die vrou speel 'n deurslaggewende rol in fiksie oor die Anglo-Boereoorlog, met J.R.L. van Bruggen se Die gerig as een van die heel eerste feministiese verhale wat in Afrikaans geskryf is.$^{57}$ Kyk verder ook na H.S. van Blerk se Tuin van herinnering (Kaapstad: Tafelberg, 1982), Maretha Maartens se Gezina en die bruin wind (Pretoria: HAUM-Literêr, 1990) en Franci Greyling se Helena in die tyd van tente (Kaapstad: Tafelberg, 1986). Oor die algemeen idealiseer die skrywers die vrou tydens die oorlog. Let egter ook op Jeanette Ferreira se Charlotta en Elsa Joubert se Die reise van Isobelle.

- Vrouens en kinders wat vir die grootste deel van die duur van die guerrilla-fase te velde rondgetrek het en daarin geslaag het om uit die hande van die Britse kolonnes te bly - byvoorbeeld in Christoffel Coetzee se Op soek na generaal Mannetjies Mentz en Lettie Viljoen (Ingrid Winterbach) se Niggie. ${ }^{58}$

- Krygsgevangenekampe - die herinneringe van diegene wat as "bannelinge" oorsee gestuur is, is as boustof vir avontuur- en kinderverhale gebruik. Kyk byvoorbeeld na P.J. Nienaber se Nag op St. Helena (Bloemfontein: Nasionale Pers, 1944) en Eleanor Baker se Groot duiwels dood.

- Die plek en rol van swart en bruin mense, en hul belewing van die oorlog - hul plek en rol word sedert 1903 deur fiksieskrywers erken, maar hulle bly newekarakters, behalwe in A.H.M. Scholtz se Vatmaar en Afdraai. Kyk ook na Karel Schoeman se Verliesfontein, waar onder meer Abraham Esau se tragiese geskiedenis volledig beskryf word. Namate daar in die geskiedenis meer navorsing oor swart en bruin mense se rol in die oorlog gedoen is, figureer hulle ook sterker in oorlogsfiksie. ${ }^{59}$ Kyk ook weer na Ingrid Winterbach se Niggie.

57 Van der Merwe, "Verhale oor die Anglo-Boereoorlog", p. 91.

58 Hierdie Hertzogprys-bekroonde werk het reeds besonder baie aandag geniet. Kyk bv. M. Botha en H. van Vuuren, “'Onze strijd, onze heldedood ...': kreatiewe verwerking van patriotiese stof uit Celliers se oorlogsdagboek in Winterbach se 'niggie"”, Tydskrif vir Geesteswetenskappe 48(1), Maart 2008, pp. 111-128; M. Botha en H. van Vuuren, "Eksperiment en intertekstualiteit in 'niggie' ", Journal of Literary Studies 23(1), Maart 2007, pp. 63-80; H. du Plooy, "Afstand en belewenis: liminale ruimtes en oorlewing in 'niggie' deur Ingrid Winterbach", Literator 27(1), April 2006, pp. 1-22; M. Botha en H. van Vuuren, "Die enigmatiese aard van die trieksterfiguur in Ingrid Winterbach se 'niggie', Tydskrif vir Letterkunde 45(2), November-Desember 2008, pp. 48-71; M.E. Botha, Eksperiment en intertekstualiteit: 'n studie van Ingrid Winterbach se "Niggie" (2002) en die "Oorlogsdagboek van Jan F.E. Celliers 1899-1902" (1978), asook ander Anglo-Boereoorlog tekste (M.A., Nelson Mandela Metropolitaanse Universiteit, Port Elizabeth, 2006), passim. 
- Verhoudinge tussen wit en swart en bruin tydens die oorlog - kyk byvoorbeeld na G.H. Franz se Moeder Poulin (Kaapstad: Nasionale Pers, 1946), waarin 'n blanke oor die swart mense se ervaringe tydens die oorlog en die samewerking tussen wit en swart skryf en J.H. Immink se Die dasvelmasker (Pretoria: J.P. van der Walt, 1967), wat onder meer handel oor hoe 'n swart (bruin?) persoon 'n blanke motiveer om die stryd teen die Britte aan te knoop.

- Mediese aspekte - kyk byvoorbeeld na Wille Martin se boeke Die kolonel se dogter (Pretoria: Daan Retief, ca. 1984) en Lied van die balalaika (Kaapstad: Tafelberg, 1983), wat handel oor liefdesverhoudinge tussen buitelandse verpleegsters en Boere.

- Verraad - byvoorbeeld die joiners, na wie reeds verwys is. ${ }^{60}$

- Heropbou ná die oorlog - kyk byvoorbeeld na Eleanor Baker se Groot duiwels dood.

- Liefdestemas - hoofsaaklik in populêre romans (ontspanningsliteratuur), byvoorbeeld Schalkie van Wyk se Aan die einde van die reënboog (Pretoria: Retief, ca. 1981), Fritz Steyn se Liefde en oorlog (Kaapstad: Human \& Rousseau, 1985), Hennie Human se Die eerste winter (Pretoria: Van der Walt, 1999) en Peet Venter se Vlieg, duifie, vlieg! (Pretoria: Van der Walt, 1999).

Die Afrikaanse literêre werke wat die Anglo-Boereoorlog as agtergrond gebruik, is kaleidoskopies en multiperspektiwies van aard. Karakters oor wie daar nog heelwat historiese navorsing gedoen kan word en wie se eskapades hul uitstekend leen tot die skep van romans (en die maak van vollengte-rolprente) is onder meer Scotty Smith en Fritz Duquesne. Ander aspekte wat ook nog literêr ontgin kan word, is onder meer die stryd in Kaapland (wat die vorm van 'n burgeroorlog aangeneem het) en die verhoudinge tussen Boer en Brit (blankes) enersyds en swart en bruin ("nie-blankes") andersyds, die rol en belewing van swart en bruin mense tydens die oorlog, die Boere se optrede teenoor (in sommige gevalle teregstelling van) verraaiers in eie geledere, godsdienstige aspekte, en die verhoudinge tussen die republikeinse burgers en die buitelanders.

\section{Slotperspektiewe}

Feite (soos byvoorbeeld in onderafdeling 2 kortliks uiteengesit) mag nooit geïgnoreer word nie, maar historici moet bewus wees van die moontlikhede wat fiksie (soos byvoorbeeld in onderafdeling 3 uiteengesit) bied ten opsigte van 'n beter begrip van die verlede. Geskiedenis word immers in en deur middel van taal bedryf. Dit is seker ook nie toevallig dat in Engels "history" en "story" so naby aan mekaar lê nie. Of moet daar eerder ook verwys word na "herstory" en "our-story"? In die dialektiek tussen hede en verlede speel die verbeelding 'n belangrike rol. 'n Mens sou ook kon beweer dat dit soms nodig mag wees om in literêre tekste die verlede diskreet te "verdraai" ten einde mense met wie ander maklik kan identifiseer, aan die woord te stel - en só ook historiese waarhede aan 'n wyer gehoor bekend te stel.

Die vooraanstaande Nederlandse historikus Jan Huizinga het (in die eerste helfte van die twintigste eeu) geskiedenis omskryf as 'n geestelike vorm waarin diegene wat tot 'n bepaalde kultuurgroep behoort, rekenskap gee van hul verlede. ${ }^{61}$ Dít word tradisioneel gedoen deur die

60 Kyk ook C.N. van der Merwe, "Waarheid en versoening by Van Melle se drie joiners", Stilet 10(1), 1998, pp. 35-41.

61 J. Huizinga, Verzamelde werken 7: Geschiedwetenschap; hedendaagsche cultuur (Haarlem, 1950), p. 102. 
verlede te bestudeer deur middel van veral boeke en/of, as jy ' $n$ akademikus is of 'n baie besondere belangstelling in geskiedenis het, deur ook artikels te lees en/of oorspronklike dokumente te bestudeer. Deur letterkunde te lees, kan egter ook van die verlede rekenskap gegee word.

Naas Huizinga se omskrywing van geskiedenis is daar uiteraard ook nog talle ander definisies. In sy diepste wese is geskiedenis egter die verhaal van die verlede en moet die historikus dus ook 'n storie vertel, en dit goed vertel. Die verhaal wat hy of sy vertel, is nie noodwendig "mooi" nie (want dit kan of mag die verhaal van byvoorbeeld die Nazi-konsentrasiekampe nooit wees nie), maar dit móét waar wees. Al is die karakters gewoonlik fiktief, kan goeie literêre werke ook 'n belangrike bydrae lewer tot die blootlegging van die waarheid omtrent die verlede. ${ }^{62}$ Die goeie skrywer, wat ook 'n populêre skrywer kan wees, bereik immers baie méér mense as wat die historikus (hoe 'n knap wetenskaplike hy of sy ook al mag wees) ooit van kan droom om te bereik. Skrywers in die algemeen speel dus 'n belangrike rol in die sogenaamde "gewone" of algemene lesers se beeldvorming omtrent die verlede en kan dus die algemene publiek help om rekenskap van hul verlede te gee. Juis daarom rus daar egter 'n groot verantwoordelikheid op die skrywers van fiksie om versigtig met historiese feite om te gaan. Hulle navorsing moet inderdaad van 'n hoë gehalte wees en op dieselfde vlak as wat van historici verwag word. Indien dit nie die geval is nie, is hulle misleiers en valse profete.

In die Suid-Afrikaanse konteks moet natuurlik deurgaans in gedagte gehou word dat naas die feit dat elk van die onderskeie kultuurgroepe (Afrikaanses, Engelssprekendes, Zoeloes, Sotho's en dies meer) van hul eie (beperkte) kulturele verlede moet rekenskap gee, kombinasies van hierdie kultuurgroepe, maar uiteindelik ook alle Suid-Afrikaners sáám moet rekenskap gee van hul gedeelde verlede. 'n Omvangryke stryd soos dié van die AngloBoereoorlog het immers alle Suid-Afrikaners op een of ander wyse geraak, en alle SuidAfrikaners deel ook'n gemeenskaplike koloniale verlede.

Dit is opvallend, aldus Cas van Rensburg, "hoe verskriklik seer die neerslag van 'n eeu-oue ervaring nog in die bewussyn van ons hedendaagse skrywers lê. Die gedagte kom by 'n mens op, half onwillekeurig en nié noodwendig welkom nie, dat in hierdie herbelewenis deur soveel stories en vertellinge dalk 'n ontlading en suiwering skuil waarop die Afrikaanse kollektiewe onderroersels reeds geslagte wag". ${ }^{63}$ Of het dit eerder iets te make met die feit dat 1994 'n onherroeplike waterskeidingsjaar in die geskiedenis van die Afrikaner (en ander SuidAfrikaners) was toe bykans drie en 'n halwe eeue se blanke heerskappy finaal beëindig is en veral die blanke Afrikaanssprekende 'n onsekere toekoms ingedwing is. 'n Natuurlike reaksie is om laer te trek, ook kultureel gesproke, en histories, kultureel, literêr en andersins bestek op te neem en rekenskap te gee. Deur die verlede te bestudeer en te beskryf - ook deur middel van historiese romans en kortverhale - word uiteraard ook rekenskap gegee en perspektief verkry. Letterkunde kan inderdaad soms ook die funksie van 'n tipe waarheids- en versoeningskommissie vervul. Dit is betekenisvol dat die oplewing en hernieude belangstelling in die Anglo-Boereoorlog, wat in die eerste plek saamgehang het met die honderdjarige herdenking van dié stryd, in 'n tydvak van politieke Sturm und Drang vir die

62 Kyk bv. M. Rossouw, “'n Vernuwende blik op die verlede: Afrikaanse oorlogsliteratuur as (alternatiewe) bron van geskiedskrywing oor die indiwidu" in M. Hattingh en H. Willemse (reds.), Vernuwing in die Afrikaanse letterkunde (Bellville, 1994), pp. 253-264; W.A. de Klerk, "Letterkunde as geskiedenis: die oorvloediger geskiedenis", Tydskrif vir Letterkunde 28(1), 1990, pp. 1-11. 
Afrikaanssprekende, maar ook vir die breër Suid-Afrikaanse gemeenskap, plaasgevind het (tydens en na afloop van die werksaamhede van die land se Waarheids- en Versoeningskommissie, WVK). Sedert 2002 het daar egter nie veel nuwe literêre tekste oor die Anglo-Boereoorlog die lig gesien nie.

Die historiese en literêre waarheid hoef nie noodwendig teenoor mekaar te staan nie; trouens, hulle moet mekaar aanvul. ${ }^{64}$ In die huidige tydsgewrig worstel sommige Afrikaanssprekendes om vrede te maak met die post-apartheid politieke bedeling. Juis in dié tye is dit belangrik dat Afrikaanssprekendes hul geskiedenis behoorlik sal bestudeer en sal besef dat die verlede (hul geskiedenis) nie noodwendig as knellende bande bejeën moet word nie, maar eerder as ankertoue. Wie vrede gemaak het met sy of haar verlede het 'n beter kans op 'n rooskleurige toekoms. Só iemand kan waarskynlik ook makliker vergewe, sonder om noodwendig te vergeet. Die skrywers van literêre werke kan die leser help om op 'n ontspannende (dog soms ook ontstellende) wyse die waarheid van die verlede te ontdek op weg na 'n versoening met daardie verlede en met die ander inwoners van die land.

Deur verhale te lees wat in die verlede afspeel, word lesers sensitief gemaak vir hul geskiedenis en onthou hulle ook iets omtrent hul verlede en hopelik ook iets oor die sinloosheid van oorlog. Naas die geskiedenis-as-wetenskap, kan ook die letterkunde dus 'n belangrike rol speel om die toekoms van ons verlede te verseker. ${ }^{65}$

64 Wat betref bronne oor die metodologie van geskiedenis, waarin daar onder meer na die historiese roman as bron, en verwante sake, verwys word, kyk bv. R.C. Williams, The historian's toolbox: a student's guide to the theory and craft of history (2de uitgawe, New York, 2007), pp. 138-141; R.H. Canary en H. Kozicki (reds.), The writing of history: literary form and historical understanding (Madison, 1978), pp. 339; M. Bentley (red.), Companion to historiography (London, 1997), pp. 865-866.

65 Kyk C. Bundy, "The future of our past: understanding South African history" (lesing gelewer tydens die Graham's Town Kunsfees se Winterskool, 2.7.1999) en A. Wessels, "Om die toekoms van ons verlede te verseker: fasette betreffende die aard en uitdagings vir die geskiedenis-as-wetenskap vandag in Suid-Afrika", Joernaal vir Eietydse Geskiedenis 34(2), Junie 2009, pp. 235-247. 